\title{
PROTECTIVE EFFECT OF HI-6 AND TRIMEDOXIME COMBINATION IN MICE ACUTELY POISONED WITH TABUN, DICHLORVOS OR HEPTENOPHOS
}

\author{
ANTONIJEVIĆ BILJANA*, VUČINIĆ SLAVICA** and ĆUPIĆ V*** \\ *University of Belgrade, Faculty of Pharmacy, Serbia \\ **National Poison Control Centre, MMA, Belgrade, Serbia \\ ***University of Belgrade, Faculty of Veterinary Medicine, Serbia \\ (Received 6th October 2011)
}

The aim of this study was to compare the protective effect of two individual oximes (HI-6 and trimedoxime) with their combination in mice acutely poisoned with tabun, dichlorvos or heptenophos. Oxime HI-6 did not protect experimental animals against either dichlorvos, heptenophos or tabun. Trimedoxime was very effective against all three OPs. The $E D-50_{0}$ doses of trimedoxime necessary to protect $50 \%$ of animals after the simultaneous administration of OPs and oxime were 42.18, 14.97 and $32.08 \mu \mathrm{mol} / \mathrm{kg}$ in dichlorvos, heptenophos and tabun poisoning, respectively. Half-time of efficacy in the tabun protocol was approximately three and two times longer than in the protocol for heptenophos and dichlorvos, respectively indicating also that trimedoxime is very potent in counteracting tabun toxicity. Addition of trimedoxime significantly improved the protective effect of HI-6 in acute tabun poisoning. When dichlorvos or heptenophos were used, addition of trimedoxime generally improved the antidotal effect of HI-6, but still lower protection was obtained than in the case when trimedoxime alone was administered. The investigations of different oxime combinations have indicated that application of a mixture of two oximes represents a promising antidotal approach.

Key words: dichlorvos, heptenophos, HI-6, mice, tabun, trimedoxime

\section{INTRODUCTION}

Organophosphate (OP) compounds are the most widely used group of insecticides in the world. OP insectide poisoning results from occupational, accidental and intentional exposure (Jokanović et al., 2010). Their acute toxicity causes a hazard both to professional and amateur users, as well as to domestic and wild animals accidentally exposed (Ćupić et al., 1984; Ćupić, 1998). A group of OP compounds also includes nerve agents (sarin, soman, tabun, VX) that are considered to be the most dangerous chemical warfare agents. Due to their high toxicity, OPs bear a potential risk to be used in war conflicts and terrorist attacks. 
OPs or their active metabolites are electrophilic compounds with moderate to high potency for phosphylating (denotes both phosphorylation and phosphonylation) the serine hydroxyl group located in the active site of acetylcholinesterase (AChE, EC 3.1.1.7). Their reactivity varies depending upon the chemical structure. The primary molecular mechanism of OPs is inhibition of AChE producing excessive acetylcholine (ACh) accumulation in the muscular and nerval synaptic clefts (Mileson et al., 1998; Pope et al., 2005). Acute cholinergic crisis immediately follows exposure to OP and includes signs and symptoms resulting from hyperstimulation of central and peripheral muscarinic and nicotinic, receptors.

The current view of treatment of OP poisoning includes three strategies, i.e. the use of an anticholinergic drug (e.g. atropine), cholinesterase-reactivating agents (e.g. oximes) and anticonvulsant drugs (e.g. benzodiazepines). Oximes, as a part of antidotal therapy, ensure the recovery of the phosphylated enzyme via a process denoted as reactivation of inhibited AChE (Antonijević and Stojiljković, 2007). Reactivation of inhibited AChE represents removal of the phosphyl moiety from the AChE active site serine. However, both experimental results and clinical findings have demonstrated that different oximes are not equally effective against poisonings caused by structurally different OP compounds. While most oximes (pralidoxime, trimedoxime, obidoxime, $\mathrm{HI}-6$ ) are sufficiently effective to reactivate sarin or VX-inhibited AChE, their potency to reactivate soman, or tabun-inhibited AChE is generally low (Dawson, 1994; Kassa et al., 2007; 2008). It could be summarised that, at least toxic per se, $\mathrm{HI}-6$ is superior to other oximes in case of soman poisoning but ineffective against tabun poisoning. However, completely opposite findings have been demonstrated regarding trimedoxime (TMB-4). It is a powerful reactivator and was the first oxime efficient in the treatment of animals intoxicated with tabun (Maksimović et al., 1980; Schoene and Oldiges, 1973; Bokonjić et al., 1993, Antonijević and Stojiljković, 2007). At the same time it is, however, the most toxic oxime, demonstrated in mice to have a median lethal dose (LD-50) of 3, 4 and 8 times less than the ones for obidoxime, pralidoxime and HI-6, respectively (Clement, 1981).

Experimental studies on oxime ability to reverse toxicity of OP insecticides have shown limited potential of $\mathrm{HI}-6$ and pralidoxime to antagonize effects of a number of insecticides, while the most efficient oximes were TMB-4 and obidoxime (Jokanović and Maksimović, 1995; Worek et al., 1996; Antonijević et al., 2005).

Thus far, numerous attempts have been made to improve the antidotal properties of the conventional mono- and bis-pyridinium mono(di)- oximes, by modifying their structure, as well as by introduction of other heterocyclic systems such as imidazolium, quinuclidinium, pyridinium-imidazolium, pyridiniumquinuclidinium and quinuclidinium-imidazolium compounds (Maksimović et al., 1980; Kassa and Cabal, 1999; Kuca et al., 2003; 2005; Promožić et al., 2004; Musilek et al., 2007). Besides, another approach to the issue belongs to those research activities gathered around the idea of two oximes in a combination against OPs. Beneficial action of different oximes combinations has been assessed predominantly against OP nerve agents and with a special attention 
Acta Veterinaria (Beograd), Vol. 62, No. 2-3, 123-135, 2012.

Antonijević Biljana et al.: Protective effect of $\mathrm{HI}-6$ and trimedoxime combination

in mice acutely poisoned with tabun, dichlorvos or heptenophos

towards soman and tabun (Clement et al., 1987; Bokonjić et al., 1993; Kassa et al., 2009; 2010).

Concerning all these data on oximes efficacy, in this paper the protective effect of HI-6 and TMB-4 combination was examined not only in acute poisoning with nerve agent tabun, but also against two insecticides, heptenophos and dichlorvos using in vivo model. Thus, the main aim of this study was to compare the protective effect of two individual oximes (HI-6 and TMB-4) with their mixture in which predominant component is $\mathrm{HI}-6$ due to its significantly lower acute toxicity.

\section{MATERIALS AND METHODS}

\section{Experimental animals}

Male albino mice (18-24 g) were obtained from the Military Medical Academy, Belgrade. The animals were housed at least one week before the experiment started with free access to food and water and maintained on a $12 \mathrm{~h}$ light/dark cycle (lights on at 7:00 a.m.). The study protocol was based on the Guidelines for Animal Study no. 282-12/2009 (Ethics Committee of the Military Medical Academy, Belgrade, Serbia).

Chemicals. Trimedoxime (1,1'-trimethylene bis(4-hydroxyimino methyl) pyridinium dichloride) (99\%), HI-6 (1-(2-hydroxyiminomethyl-1-pyridinio)-3-(4carbamoyl-1-pyridinio)-2-oxapropanedichloride) (99\%) and tabun (99\%) were obtained from the Military Medical Academy. Dichlorvos (2,2-dichlorovinyldimethylphosphate) (94.0\%) and heptenophos ((7-chlorobicyclo[3.2.0]hepta-2,6dien-6-yl)dimethylphosphate) $(92.0 \%)$ were purchased from domestic commercial sources.

Stock solutions of organophosphates were prepared in isopropanol. Oximes were dissolved in distilled water and diluted to the required concentration immediately before use.

\section{Experimental procedures}

Experimental animals $(\mathrm{n}=5)$ were pretreated intravenously with increasing doses of antidotes at different time intervals (5-60 min.) before a lethal intravenous dose (1.3 LD-50) of organophosphates. When administered in combination, the dose of TMB-4 was equal to $10 \%$ of $\mathrm{HI}-6$ dose. All the solutions were administered intravenously via the tail vein at a volume of $0.1 \mathrm{~mL} / 20 \mathrm{~g}$ of body mass.

Median lethal doses of tested compounds and median effective doses of oxime (ED-50t) were calculated according to the method of Litchfield and Wilcoxon (1949), with 95\% confidence limits. Median effective doses of the oxime along with the corresponding pretreatment time intervals were used to calculate ED-50 at null time (ED-50 $)$ and efficacy half-time ( $\mathrm{t}_{1 / 2}$ eff.) (Schoene et al. 1988).

Statistical analysis

Relative potential of antidotes used in the study has been assessed by $2 \times 2$ essay (PHARM - Pharmacologic Calculation System, ver. 4.0, 1986 SpringerVerlag, New York, USA). 


\section{RESULTS}

Data on acute intravenous toxicity of OPs and oximes are given in Table 1. Mice received lethal doses of tabun or dichlorvos have shown typical signs of cholinesterase inhibition. Time to their onset was short and death usually occurred within 1-5 min. after administration of a lethal dose. This very short survival time of mice that were not pretreated with oxime imposed the use of an experimental model based on administration of the oxime at various times before intravenous injection of organophosphorus compounds (Schoene et al. 1988).

Table 1. Median lethal doses (LD-50) of organophosphates and oximes

\begin{tabular}{|c|c|}
\hline & $\begin{array}{c}\text { LD-50 (95\% confidence interval), } \\
\mu \mathrm{mol} / \mathrm{kg}\end{array}$ \\
\hline Tabun & $0.80(0.70-0.91)$ \\
\hline Dichlorvos & $22.17(16.24-30.22)$ \\
\hline Heptenophos & $198.68(163.72-208.41)$ \\
\hline TMB-4 & $238.61(199.92-284.78)$ \\
\hline HI-6 & $496.80(420.02-587.61)$ \\
\hline
\end{tabular}

It is evident that LD-50 of HI- 6 is about 2 times higher than LD-50 of TMB-4 which makes oxime HI-6 the more desirable antidotal option in acute OPs poisoning. Additionaly, maximal dose of HI-6 has been limited to approximetely $50 \%$ of its LD- 50 .

Oxime $\mathrm{HI}-6$, primarely effective against the nerve agent, i.e. soman, even administered in relatively high doses, did not protect experimental animals against either dichlorvos, heptenophos or tabun (Table 2).

Table 2. Protective effect of HI-6 given 5 minutes before 1.3 LD-50 i.v. of organophosphate

\begin{tabular}{|l|c|c|c|}
\hline \multirow{2}{*}{ Organophosphate } & \multicolumn{2}{|c|}{ HI-6 } & Survival rate* $^{*}$ \\
\cline { 2 - 4 } & $\mu \mathrm{mol} / \mathrm{kg}$ & \% of LD-50 & $(\%)$ \\
\hline \hline \multirow{2}{*}{ Dichlorvos } & 150.82 & 30.0 & 0 \\
\cline { 2 - 4 } & 300.03 & 60.0 & 0 \\
\hline \multirow{2}{*}{ Tabun } & 125.68 & 25.3 & 0 \\
\cline { 2 - 4 } & 217.17 & 43.7 & 10 \\
\hline \multirow{2}{*}{ Heptenophos } & 111.35 & 22.4 & 0 \\
\cline { 2 - 4 } & 222.70 & 44.8 & 10 \\
\hline
\end{tabular}

*Each group has 10 animals

Expectedly, TMB-4 was very effective against all three OPs, but especially in the case of tabun poisoning where protection is afforded even when administered 60 min before the poison (Tables 3, 4 and 5). 
Acta Veterinaria (Beograd), Vol. 62, No. 2-3, 123-135, 2012.

Antonijević Biljana et al.: Protective effect of $\mathrm{HI}-6$ and trimedoxime combination

in mice acutely poisoned with tabun, dichlorvos or heptenophos

Table 3. Protective effect of TMB-4 in mice poisoned with 1.3 LD-50 i.v. of dichlorvos

\begin{tabular}{|c|c|c|c|c|c|c|c|c|}
\hline \multirow{2}{*}{$\begin{array}{c}t^{a} \\
(\min )\end{array}$} & \multicolumn{2}{|c|}{ TMB-4 } & \multirow{2}{*}{$\begin{array}{c}\text { ED-50, } \mu \mathrm{mol} / \mathrm{kg} \\
\text { (confidence interval) }\end{array}$} & \multicolumn{5}{|c|}{ Death time ${ }^{b}(\min )$} \\
\hline & $(\mu \mathrm{mol} / \mathrm{kg})$ & (\% of LD-50) & & 1 & 2 & 3 & 4 & 5 \\
\hline \multirow{4}{*}{5} & 34.06 & 14.3 & \multirow{4}{*}{$\begin{array}{c}50.49 \\
(36.39-70.03)\end{array}$} & 1 & 2 & & & 1 \\
\hline & 44.28 & 18.6 & & 1 & 2 & & & \\
\hline & 57.28 & 24.1 & & & 1 & & 1 & \\
\hline & 74.85 & 31.4 & & 1 & & & & \\
\hline \multirow{4}{*}{12.5} & 46.91 & 19.7 & \multirow{4}{*}{$\begin{array}{c}66.36 \\
(59.12-74.43)\end{array}$} & 1 & 2 & 1 & 1 & \\
\hline & 56.32 & 23.6 & & 1 & 2 & & 1 & \\
\hline & 67.57 & 28.3 & & 1 & 1 & & & 1 \\
\hline & 81.09 & 34.0 & & & & & & \\
\hline \multirow{4}{*}{20} & 67.57 & 28.3 & \multirow{4}{*}{$\begin{array}{c}88.81 \\
(73.28-107.65)\end{array}$} & 1 & 2 & 1 & & \\
\hline & 81.09 & 34.0 & & 1 & 1 & 1 & 1 & \\
\hline & 97.29 & 40.8 & & & 1 & & & \\
\hline & 116.75 & 48.9 & & & & & & 1 \\
\hline \multirow{4}{*}{27.5} & 81.09 & 34.0 & \multirow{4}{*}{$\begin{array}{c}114.11 \\
(96.79-134.58)\end{array}$} & 1 & 2 & 1 & 1 & \\
\hline & 97.29 & 40.8 & & 1 & & 1 & 1 & 1 \\
\hline & 116.75 & 48.9 & & 1 & 1 & & & \\
\hline & 140.09 & 58.7 & & & & & & 1 \\
\hline
\end{tabular}

${ }_{\text {ppretreatment time }}$

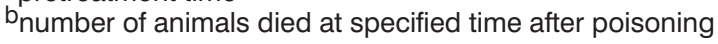

Table 4. Protective effect of TMB-4 in mice poisoned with 1.3 LD-50 i.v. of heptenophos

\begin{tabular}{|c|c|c|c|c|c|c|c|c|}
\hline \multirow{2}{*}{$\begin{array}{c}t^{\mathrm{a}} \\
(\min )\end{array}$} & \multicolumn{2}{|c|}{ TMB-4 } & \multirow{2}{*}{$\begin{array}{c}\text { ED-50, } \mu \mathrm{mol} / \mathrm{kg} \\
\text { (confidence interval) }\end{array}$} & \multicolumn{5}{|c|}{ Death time ${ }^{b}(\min )$} \\
\hline & $(\mu \mathrm{mol} / \mathrm{kg})$ & (\% of LD-50) & & 1 & 2 & 3 & 4 & 5 \\
\hline \multirow{4}{*}{5} & 8.40 & 2.6 & \multirow{4}{*}{$\begin{array}{c}16.46 \\
(11.06-24.49)\end{array}$} & 1 & 2 & & 1 & \\
\hline & 13.99 & 5.7 & & 1 & 1 & & 1 & 1 \\
\hline & 20.99 & 8.8 & & & & 1 & 1 & \\
\hline & 27.99 & 11.7 & & & & & & \\
\hline \multirow{4}{*}{20} & 27.99 & 11.7 & \multirow{4}{*}{$\begin{array}{c}68.62 \\
(55.98-84.11)\end{array}$} & 2 & & 2 & 1 & \\
\hline & 55.98 & 23.5 & & 2 & 1 & & 1 & \\
\hline & 69.98 & 29.3 & & 1 & 1 & 1 & & 1 \\
\hline & 83.97 & 35.2 & & & & 1 & & \\
\hline
\end{tabular}


cont. Table 4

\begin{tabular}{|c|c|c|c|c|c|c|c|c|}
\hline \multirow{2}{*}{$\begin{array}{c}t^{a} \\
(\min )\end{array}$} & \multicolumn{2}{|c|}{ TMB-4 } & \multirow{2}{*}{$\begin{array}{c}\text { ED-50, } \mu \mathrm{mol} / \mathrm{kg} \\
\text { (confidence interval) }\end{array}$} & \multicolumn{5}{|c|}{ Death time ${ }^{b}$ (min) } \\
\hline & $(\mu \mathrm{mol} / \mathrm{kg})$ & (\% of LD-50) & & 1 & 2 & 3 & 4 & 5 \\
\hline \multirow{4}{*}{27.5} & 69.98 & 29.3 & \multirow{4}{*}{$\begin{array}{c}99.09 \\
(87.06-112.79)\end{array}$} & & 2 & 2 & 1 & \\
\hline & 83.97 & 35.2 & & 1 & 1 & & 1 & 1 \\
\hline & 97.96 & 41.0 & & & 2 & 1 & & \\
\hline & 111.96 & 46.9 & & & & & & 1 \\
\hline \multirow{4}{*}{40} & 97.96 & 41.0 & \multirow{4}{*}{$\begin{array}{c}145.02 \\
(118.79-177.02)\end{array}$} & 1 & 1 & 1 & 2 & \\
\hline & 111.96 & 46.9 & & 1 & 2 & 1 & & \\
\hline & 139.95 & 58.6 & & & 1 & 1 & 1 & \\
\hline & 167.94 & 70.4 & & & & 2 & & \\
\hline
\end{tabular}

${ }^{a}$ pretreatment time; ${ }^{b}$ number of animals died at specified time after poisoning

Table 5. Protective effect of TMB-4 in mice poisoned with 1.3 LD-50 i.v. of tabun

\begin{tabular}{|c|c|c|c|c|c|c|c|}
\hline \multirow{2}{*}{$\begin{array}{c}t^{a} \\
(\min )\end{array}$} & \multicolumn{2}{|c|}{ TMB-4 } & \multirow{2}{*}{$\begin{array}{c}\text { ED-50, } \mu \mathrm{mol} / \mathrm{kg} \\
\text { (confidence interval) }\end{array}$} & \multicolumn{4}{|c|}{ Death time $^{\mathrm{b}}$ (min) } \\
\hline & $(\mu \mathrm{mol} / \mathrm{kg})$ & (\% of LD-50) & & 1 & 2 & 3 & 4 \\
\hline \multirow{4}{*}{5} & 26.20 & 11.0 & \multirow{4}{*}{$\begin{array}{c}35.26 \\
(31.57-39.38)\end{array}$} & 2 & 2 & & 1 \\
\hline & 31.21 & 13.1 & & 2 & 2 & & \\
\hline & 31.17 & 15.6 & & 1 & 1 & & \\
\hline & 44.25 & 18.5 & & & & & \\
\hline \multirow{4}{*}{20} & 36.89 & 15.5 & \multirow{4}{*}{$\begin{array}{c}48.50 \\
(42.74-55.02)\end{array}$} & 2 & 2 & 1 & \\
\hline & 44.28 & 18.6 & & 2 & 1 & & \\
\hline & 53.12 & 22.3 & & 1 & & & \\
\hline & 63.76 & 26.7 & & & & & \\
\hline \multirow{4}{*}{40} & 53.12 & 22.3 & \multirow{4}{*}{$\begin{array}{c}73.08 \\
(50.97-104.79)\end{array}$} & 2 & 1 & 1 & \\
\hline & 63.76 & 26.7 & & 2 & 1 & & \\
\hline & 76.49 & 32.1 & & 1 & 1 & & \\
\hline & 91.80 & 38.5 & & 1 & 1 & & \\
\hline \multirow{4}{*}{60} & 76.49 & 32.1 & \multirow{4}{*}{$\begin{array}{c}108.14 \\
(96.36-121.35)\end{array}$} & 3 & 2 & & \\
\hline & 91.80 & 38.5 & & 3 & 1 & & \\
\hline & 119.31 & 50.0 & & 3 & & & \\
\hline & 143.18 & 60.0 & & & & & \\
\hline ED-5 & $=32.08$ & $\mathrm{nol} / \mathrm{kg} ; \mathrm{t}_{1 / 2}=$ & $6.00 \mathrm{~min}$ & & & & \\
\hline
\end{tabular}

${ }^{a}$ pretreatment time; ${ }^{b}$ number of animals died at specified time after poisoning 
Acta Veterinaria (Beograd), Vol. 62, No. 2-3, 123-135, 2012.

Antonijević Biljana et al.: Protective effect of $\mathrm{HI}-6$ and trimedoxime combination

in mice acutely poisoned with tabun, dichlorvos or heptenophos

The ED-50 doses of TMB-4 necessary to protect $50 \%$ of animals after the simultaneous administration of OPs and oxime were 42.18, 14.97 and $32.08 \mu \mathrm{mol} / \mathrm{kg}$ in dichlorvos, heptenophos and tabun poisoning, respectively. Half-time of efficacy in the protocol with tabun was approximately three and two times longer than in the protocol with heptenophos and dichlorvos, respectively indicating also that TMB-4 is very potent in counteracting tabun toxicity.

In order to improve antidotal potency of $\mathrm{HI}-6$ alone, it has been applied in a combination with TMB-4 (Tables 6, 7 and 8).

Table 6. Protective effect of HI-6 and TMB-4 combination in mice poisoned with 1.3 LD-50 i.v. of dichlorvos

\begin{tabular}{|c|c|c|c|c|c|c|c|c|}
\hline \multirow{2}{*}{$\begin{array}{c}t^{a} \\
(\min )\end{array}$} & \multirow{2}{*}{$\begin{array}{c}\mathrm{HI}-6 \\
(\mu \mathrm{mol} / \mathrm{kg})\end{array}$} & \multirow{2}{*}{$\begin{array}{c}\text { TMB-4 } \\
(\mu \mathrm{mol} / \mathrm{kg})\end{array}$} & \multirow{2}{*}{$\begin{array}{c}\text { HI-6 } \\
\text { (\% of LD-50) }\end{array}$} & \multirow{2}{*}{$\begin{array}{c}\text { ED-50, } \mu \mathrm{mol} / \mathrm{kg} \\
\text { (confidence interval) }\end{array}$} & \multicolumn{4}{|c|}{ Death time $^{\mathrm{b}}$ (min) } \\
\hline & & & & & 1 & 2 & 3 & 4 \\
\hline \multirow{4}{*}{1} & 33.84 & 3.38 & 6.8 & \multirow{4}{*}{$\begin{array}{c}69.52 \\
(50.01-96.63)\end{array}$} & 3 & 2 & & \\
\hline & 50.51 & 5.05 & 10.2 & & 2 & 2 & & \\
\hline & 72.75 & 7.27 & 14.6 & & 1 & & 1 & \\
\hline & 104.76 & 10.48 & 21.1 & & & & & 1 \\
\hline \multirow{4}{*}{5} & 150.82 & 15.08 & 30.4 & \multirow{4}{*}{$\begin{array}{c}202.84 \\
(174.92-235.24)\end{array}$} & 2 & 2 & & \\
\hline & 180.99 & 18.10 & 36.4 & & 2 & 1 & 1 & \\
\hline & 217.17 & 21.72 & 43.7 & & 1 & & & 1 \\
\hline & 260.62 & 26.06 & 52.5 & & & & & \\
\hline$=0-6$ & $=53.19$ & $\mathrm{ol} / \mathrm{kg} ; \mathrm{t}$ & $=2.60 \mathrm{~min}$ & & & & & \\
\hline
\end{tabular}

${ }^{a}$ pretreatment time; ${ }^{b}$ number of animals died at specified time after poisoning

Table 7. Protective effect of $\mathrm{HI}-6$ and TMB-4 combination in mice poisoned with 1.3 LD-50 i.v. of heptenophos

\begin{tabular}{|c|c|c|c|c|c|c|c|c|}
\hline \multirow{2}{*}{$\begin{array}{c}t^{a} \\
(\min )\end{array}$} & \multirow{2}{*}{$\begin{array}{c}\mathrm{HI}-6 \\
(\mu \mathrm{mol} / \mathrm{kg})\end{array}$} & \multirow{2}{*}{$\begin{array}{c}\text { TMB-4 } \\
(\mu \mathrm{mol} / \mathrm{kg})\end{array}$} & \multirow{2}{*}{$\begin{array}{c}\text { HI-6 } \\
\text { (\% of LD-50) }\end{array}$} & \multirow{2}{*}{$\begin{array}{c}\text { ED-50, } \mu \mathrm{mol} / \mathrm{kg} \\
\text { (confidence interval) }\end{array}$} & \multicolumn{4}{|c|}{ Death time ${ }^{b}$ (min) } \\
\hline & & & & & 1 & 2 & 3 & 4 \\
\hline \multirow{4}{*}{5} & 27.84 & 2.78 & 5.6 & \multirow{4}{*}{$\begin{array}{c}135.26 \\
(76.67-238.71)\end{array}$} & 2 & 2 & 1 & \\
\hline & 55.68 & 5.57 & 11.2 & & 1 & 2 & & 1 \\
\hline & 83.51 & 8.35 & 16.8 & & & 1 & 1 & 1 \\
\hline & 111.35 & 11.13 & 22.4 & & & 1 & & \\
\hline \multirow{4}{*}{12.5} & 83.51 & 8.35 & 16.8 & \multirow{4}{*}{$\begin{array}{c}305.44 \\
(231.28-403.37)\end{array}$} & 2 & 1 & 2 & \\
\hline & 111.35 & 11.13 & 22.4 & & 1 & 2 & 1 & \\
\hline & 222.70 & 22.70 & 44,8 & & & 2 & 1 & 1 \\
\hline & 278.38 & 27.84 & 56.0 & & & 1 & 1 & 1 \\
\hline
\end{tabular}

${ }^{a}$ pretreatment time; ${ }^{b}$ number of animals died at specified time after poisoning 
Addition of TMB-4 significantly improved the protective effect of HI-6 in acute tabun poisoning. In tabun poisoning, $\mathrm{HI}-6$ given with a relatively low dose of TMB-4, provided protection even if applied 60 minutes before OP.

Table 8. Protective effect of HI-6 and TMB-4 combination in mice poisoned with 1.3 LD-50 i.v. of tabun

\begin{tabular}{|c|c|c|c|c|c|c|c|}
\hline \multirow{2}{*}{$\begin{array}{c}t^{\mathrm{a}} \\
(\min )\end{array}$} & \multirow{2}{*}{$\begin{array}{c}\mathrm{HI}-6 \\
(\mu \mathrm{mol} / \mathrm{kg})\end{array}$} & \multirow{2}{*}{$\begin{array}{c}\text { TMB-4 } \\
(\mu \mathrm{mol} / \mathrm{kg})\end{array}$} & \multirow{2}{*}{$\begin{array}{c}\text { HI-6 } \\
\text { (\% of LD-50) }\end{array}$} & \multirow{2}{*}{$\begin{array}{c}\text { ED-50, } \mu \mathrm{mol} / \mathrm{kg} \\
\text { (confidence interval) }\end{array}$} & \multicolumn{3}{|c|}{ Death time ${ }^{b}(\min )$} \\
\hline & & & & & 1 & 2 & 3 \\
\hline \multirow{4}{*}{5} & 42.11 & 4.21 & 8.5 & \multirow{4}{*}{$\begin{array}{c}55.33 \\
(49.90-61.34)\end{array}$} & 2 & 3 & \\
\hline & 50.51 & 5.05 & 10.2 & & 2 & 2 & \\
\hline & 60.62 & 6.06 & 12.2 & & & 1 & \\
\hline & 72.75 & 7.27 & 14.6 & & & & \\
\hline \multirow{4}{*}{20} & 60.62 & 6.06 & 12.2 & \multirow{4}{*}{$\begin{array}{c}79.68 \\
(63.48-100.03)\end{array}$} & 2 & 2 & \\
\hline & 72.75 & 7.27 & 14.6 & & 1 & 1 & 1 \\
\hline & 87.28 & 8.73 & 17.6 & & 1 & 1 & \\
\hline & 104.76 & 10.48 & 21.1 & & & 1 & \\
\hline \multirow{4}{*}{40} & 104.76 & 10.48 & 21.1 & \multirow{4}{*}{$\begin{array}{c}128.61 \\
(109.07-151.63)\end{array}$} & 2 & 1 & 1 \\
\hline & 125.72 & 12.57 & 25.3 & & 1 & 1 & 1 \\
\hline & 150.82 & 15.08 & 30.4 & & & 1 & \\
\hline & 180.99 & 18.10 & 36.4 & & & & \\
\hline \multirow{4}{*}{60} & 150.82 & 15.08 & 30.4 & \multirow{4}{*}{$\begin{array}{c}205.62 \\
(183.22-230.75)\end{array}$} & 3 & 1 & 1 \\
\hline & 180.99 & 18.10 & 36.4 & & 2 & 1 & 1 \\
\hline & 217.17 & 21.72 & 43.7 & & & 1 & 1 \\
\hline & 260.62 & 26.06 & 52.5 & & & & \\
\hline ED-5 & $=49.29$ & $\mathrm{ol} / \mathrm{kg} \mathrm{t}_{1 / 2}$ & $=28.94 \mathrm{~min}$ & & & & \\
\hline
\end{tabular}

${ }^{\text {apretreatment time }}$

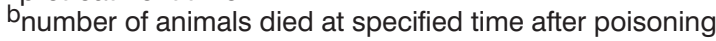

When dichlorvos or heptenophos were used, addition of TMB-4 generally improved antidotal effect of $\mathrm{HI}-6$, but still lower protection was obtained than in the case when TMB-4 alone was administered, since the combination was effective up to 5 and 12.5 minutes of pretreatment, respectively. ED-50 at null time of $49.29 \mu \mathrm{mol} / \mathrm{kg}$ calculated for tabun poisoning was similar to the one calculated for dichlorvos poisoning $(53.19 \mu \mathrm{mol} / \mathrm{kg})$, however half-time of efficacy against tabun was more than ten times longer (28.94 min vs 2.60 min), indicating a higher potency of the combination to antagonize tabun toxicity. 
Acta Veterinaria (Beograd), Vol. 62, No. 2-3, 123-135, 2012.

Antonijević Biljana et al.: Protective effect of $\mathrm{HI}-6$ and trimedoxime combination

\section{DISCUSSION}

Antidotal characteristics of conventionally used oximes can be evaluated regarding how close an oxime is to the theoretical concept of the "universal“ oxime. Many in vitro and in vivo studies have been focused on the efficacy of oximes in OP poisoning. Although some of them were very difficult to interpret due to the differences in experimental design, it could be summarised that, beside obidoxime, TMB-4 is superior to other oximes used in organophosphorus insecticide poisoning, and is also the first oxime efficient in the treatment of animals intoxicated with tabun (Antonijević and Stojiljković, 2007). Results of this study are fully in compliance with previously given notion, i.e. TMB-4 afforded relatively good protection against all three OPs used in the study and its protective effect decreased according to the following order: tabun > heptenophos > dichlorvos. Mechanistic studies have shown that TMB-4 is a powerful reactivator of diethoxy, ethylethoxy-, methylethoxy-, methylisopropoxy or diisopopoxyphosphorylated cholinesterase (Dirks et al., 1970; Schoene and Strake, 1971; Patočka, 1973). In previous experiments TMB-4 produced a significant reactivation of brain and diaphragmal $A C h E$ inhibited with dichlorvos or heptenophos (Antonijević et al., 2005). Also, in the experiments of Jokanović and Maksimović (1995), where pyridinium oximes (pralidoxime, TMB-4, LüH-6, HI-6) were administered along with atropine and diazepam to rats poisoned with 2 LD50 of organophosphorus insecticides, including dichlorvos and heptenophos, better protection was achieved when TMB-4 was used as a component of antidotal treatment. It also has a therapeutic action independent of AChEreactivation, so called "direct" pharmacological effect. Early experiments showed that TMB-4 reduced sensitivity of the small intestine to acetylcholine in guinea pigs (Hobbiger and Sadler, 1959) while Bošković and Stern (1963) proved its direct effect on the activity of the rat striated muscle. Results of Lindgren and Sundwall (1960) confirmed its strong parasympatholytic effect in animals not exposed to organophosphates. Direct effects have been later extensively investigated and used to explain overall pharmacological activity of oximes (van Helden et al., 1991). Expectidely, HI-6, another oxime used in this study, failed to antagonize toxicity produced by tabun, dichlorvos or heptenophos. Oxime HI-6 was synthesized as a powerful mean against soman, but concerning the issue on efficacy towards nerve warfare agents, the main drawback of $\mathrm{HI}-6$ is that this oxime cannot reactivate tabun-inhibited AChE (Clement, 1982). Although superior against soman, in comparison with an equimolar concentration of obidoxime that is structural analogue of TMB-4, the equimolar concentration of HI-6 induced a significantly lower level of reactivation of human erythrocyte AChE inhibited by various OP insecticides (Worek et al., 1996). Similar findings were obtained in the rat model in which it afforded weak protection against lethality caused by 29 insecticides including dichlorvos and heptenophos (Jokanović and Maksimović, 1995). Generally, better antidotal outcome of TMB-4 in relation to HI-6 could be partly explained by its pharmacokinetic properties (Milić et al., 1996). In this comparative study of HI-6 vs TMB-4 kinetics after intravenous administration to 
Acta Veterinaria (Beograd), Vol. 62, No. 2-3, 123-135, 2012. Antonijević Biljana et al.: Protective effect of $\mathrm{HI}-6$ and trimedoxime combination in mice acutely poisoned with tabun, dichlorvos or heptenophos

mice, it has been concluded that TMB-4 penetrates better into the tissues, that it is slowly transferred back into the circulation and that it remains longer in the body.

Efforts made to overcome uncertainties due to oximes inability to counteract equieffectively the toxicity of a majority of OPs, resulted in a series of newly synthesized oximes. As no broad spectrum oxime has been developed (Kassa et al., 2007), the combination of two oximes with different spectrum of their reactivating and therapeutic efficacy seems to be the rational solution for how to achieve sufficient efficacy of antidotal treatment of acute poisonings with OPs regardless of their chemical structure (Clement et al., 1987; Kovačević et al., 1989; 1991; Maksimović and Kovačević, 1989). HI-6 and TMB-4 have complementary spectrum of efficacy, thus their mixture seemed to be the promising one. Another important issue that should be addressed is the dose of the oximes used in combination. Per se toxicity of HI-6 is low, actually the lowest among the currently used oximes, whereas TMB-4 is one of the most toxic oximes (Antonijević and Stojiljković, 2007). Quantitative mixture composition depends mainly on oxime acute toxicity, but also on its sublethal toxic effects. For the combination of HI-6 and TMB-4 this means that the dose of TMB-4 should be as low as possible to the level which will not compromise the antidotal potential of the combination. Results of this study have shown that in contrast to complete inefficacy of $\mathrm{HI}-6$ alone, minimal addition of TMB-4 to HI-6 resulted in the ability of their combination to assure protection and survival of experimental animals. Protective effects of the combination decreased according to the same order as we have in the case of TMB-4 administered alone: tabun $>$ heptenophos $>$ dichlorvos. Although significant improvement of protection obtained with HI-6 alone was evident, still the combination was not as effective as TMB-4 used to be. However, safe antidotal regiments comprise an application of less toxic antidote especially because of long lasting demand for oxime therapy in severe OP poisonings. Different combinations with $\mathrm{HI}-6$ have been tested until now: in vitro human AChE reactivation properties of a mixture with obidoxime (Worek et al., 2007), protective and reactivating effects of HI-6/PAM-2 mixture in rats (Kovačević et al., 1989), protective effects of HI-6 along with TMB-4 (Kovačević et al., 1991) and protective and reactivating effects of a mixture with K203 in rats and mice (Kassa et al., 2010). All these experiments include evaluation of beneficial effects of various combinations of oximes to counteract nerve agent-induced acute intoxication. Surprisingly, there are no available data in the open literature investigating the effects of combination of oximes against OP insecticides. Results of the present study, however, have shown potential beneficial effect of HI-6/TMB-4 mixture against two insecticides whose inhibitory potential $\mathrm{HI}-6$ alone was unable to antagonize.

The investigations of different oxime combinations have indicated that application of a mixture of two oximes represents a promising antidotal concept not only in the treatment of acute poisoning with nerve agents, but also in the treatment of acute OP insecticide poisoning regardless of their chemical structure. Despite the promising data of the present study, further investigations on efficacy and toxicity in vivo are required for a final assessment of oxime combinations. 
Acta Veterinaria (Beograd), Vol. 62, No. 2-3, 123-135, 2012.

Antonijević Biljana et al.: Protective effect of $\mathrm{HI}-6$ and trimedoxime combination

in mice acutely poisoned with tabun, dichlorvos or heptenophos

ACKNOWLEDGEMENT:

This work was supported by the grant from Ministry of Science and Education, R.Serbia, No. 46009.

Address for correspondence:

Biljana Antonijević

Department of Toxicology "Akademik Danilo Soldatović"

Faculty of Pharmacy, University of Belgrade

Vojvode Stepe 450

11221 Belgrade, Serbia

E-mail: abiljana@pharmacy.bg.ac.rs

\section{REFERENCES}

1. Antonijević B, Bokonjić D, Stojiljković MP, Kilibarda V, Milovanović ZA, Nedeljković M et al., 2005, Efficacy of trimedoxime in mice poisoned with dichlorvos, heptenophos or monocrotophos, Basic Clin Pharmacol Toxicol, 96, 111-7.

2. Antonijević B, Stojiljković $M P, 2007$, Unequal efficacy of pyridinium oximes in acute organophosphate poisoning, Clin Med Res, 5, 1, 71-82.

3. Bokonjić D, Stojiljković MP, Štulić D, Kovačević V, Maksimović M, 1993, Application of response surface modeling on the efficacy of a HI-6/trimedoxime mixture against tabun and soman poisoning in rats, Arch Toxicol Kinet Xenobiot Metab, 1, 223-32.

4. Bošković $B$, Stern $P, 1963$, Uticaj nekih reaktivatora ChE na aktivnost poprečno-prugaste muskulature in vivo (m. masseter štakora), Arh Hig Rada, 14, 171-7.

5. Clement JG, 1981, Toxicology and pharmacology of bispyridium oximes - insight into the mechanism of action vs Soman poisoning in vivo, Fundam Appl Toxicol, 1, 193-202.

6. Clement JG, 1982, HI-6: reactivation of central and peripheral acetylcholinesterase following inhibition by soman, sarin and tabun in vivo in the rat, Biochem Pharmacol, 31, 1283-7.

7. Clement JG, Shiloff JD, Gennings CH, 1987, Efficacy of a combination of acetylcholinesterase reactivators, $\mathrm{HI}-6$ and obidoxime, against tabun and soman poisoning of mice, Arch Toxicol, 61, 70-5.

8. Ćupić V, Živanov D, Jezdimirović M, 1984, The effect of anticholinergics and oximes on the rate of gastrointestinal passage in mice, Arch Toxicol Kinet Xenobiot Metab, 2, 2, 461-2.

9. Ćupić V, 1998, Pesticides as causers of epidemic poisonings, Arch Toxicol Kinet Xenobiot Metab, 6, 3, 667-74.

10. Dawson RM, 1994, Review of oximes available for treatment of nerve agent poisoning, J App/ Toxicol, 14, 317-31.

11. Dirks E, Scherer A, Schmidt M, Zimmer G, 1970, Beziehungen zwischen chemischer Struktur und cholinesterase-reaktivieren der Wirkung bei einer Reihe neuer unsymmetrischer Pyridiniumsalze, Arzneim Forsch, 20, 55.

12. Hobbiger F, Sadler PW, 1959, Protection against lethal organophosphate poisoning by quaternary pyridine aldoximes, Brit J Pharmacol, 14, 190-201.

13. Jokanović M, Antonijević B, Vučinić S, 2010, Acute organophosphate and carbamate poisonings in Serbia: experience of the National Poison Control Center. In: Satoh T, Gupta CR, editors, Anticholinesterase Pesticides: Metabolism, Neurotoxicity And Epidemiology, New Jersey: John Wiley \& Sons, Inc, 481-95.

14. Jokanović M, Maksimović M, 1995, A comparison of trimedoxime, obidoxime, pralidoxime and HI-6 in the treatment of oral organophosphorus insecticide poisoning in the rat, Arch Toxicol, 70, 119-23.

15. Kassa J, Cabal J, 1999, A comparison of the efficacy of a new asymmetric bispyridinium oxime BI-6 with currently available oximes and $\mathrm{H}$ oximes against soman by in vitro and in vivo methods, Toxicology, 132, 111-8. 
16. Kassa J, Karasova J, Musilek K, Kuca K, 2008, An evaluation of therapeutic and reactivating effects of newly developed oximes (K156, K203) and commonly used oximes (obidoxime, trimedoxime, $\mathrm{HI}-6$ ) in tabun-poisoned rats and mice, Toxicology, 243, 311-6.

17. Kassa J, Kuca K, Bartosova L, Kunesova G, 2007, The development of new structural analogues of oximes for the antidotal treatment of poisoning by nerve agents and the comparison of their reactivating and therapeutic efficacy with currently available oximes, Curr Org Chem, 11, 26783.

18. Kassa J, Zdarova Karasova J, Caisberger F, Bajgar J, 2009, The influence of combinations of oximes on the reactivating and therapeutic efficacy of antidotal treatment of soman poisoning in rats and mice, Toxicol Mech Meth, 19, 547-51.

19. Kassa J, Zdarova Karasova J, Pavlikova R, Misik J, Caisberger F, Bajgar J, 2010, The influence of combinations of oximes on the reactivating and therapeutic efficacy of antidotal treatment of tabun poisoning in rats and mice, $J$ Appl Toxicol, 30, 120-4.

20. Kovačević V, Maksimović M, Deljac V, Binenfeld Z, 1991, Protective effects of mixture of oximes in poisoning by nerve chemical warfare agents, Acta Pharm Jugoslav, 41, 75-8.

21. Kovačević V, Maksimović M, Pantelić D, Vojvodić V, Binenfeld Z, 1989, Protective and reactivating effects of HI-6 PAM-2 mixture in rats poisoned with nerve chemical warfare agents, Acta Pharm Jugoslav, 39, 161-5.

22. Kuca K, Bartosova L, Jun D, Patocka J, Cabal J, Kassa $J$ et al., 2005, New quaternary pyridine aldoximes as casual antidotes against nerve agents intoxications, Biomed Pap Med Fac Univ Palacky Olomouc Czech Repub, 149, 75-82.

23. Kuca K, Bielavsky J, Cabal J, Kassa J, 2003, Synthesis of a new reactivator of tabun-inhibited acetylcholinesterase, Bioorg Med Chem Lett, 13, 3545-7.

24. Lindgren P, Sundwall A, 1960, Parasympatholytic effects of TMB-4 [1,1-trimethylene-bis(4formylpyridinium bromide)-dioxime] and some related oximes in cat, Acta Pharmacol et Toxicol, 17, 69-83.

25. Litchfield JT, Wilcoxon F, 1949, A simplified method of evaluating dose-effect experiments, $J$ Pharmacol Exp Therap, 96, 99-113.

26. Maksimović M, Bošković B, Radović L, Tadić V, Deljac V, Binenfeld Z, 1980, Antidotal effects of bispyridinium-2-monooxime carbonyl derivatives in intoxications with highly toxic organophosphorus compounds, Acta Pharm Jugoslav, 30, 151-60.

27. Maksimović $M$, Kovačević V, 1989, Protective and reactivating effects of HI-6- toxogonin mixture in rats and guinea-pigs poisoned by nerve agents, Acta Pharm Jugoslav, 39, 27-33.

28. Mileson BE, Chambers JE, Chen WL, Dettbarn W, Ehrich M, Eldefrawi AT et al., 1998, Common mechanism of toxicity: a case study of organophosphorus pesticides, Toxicol Sci, 41, 8-20.

29. Milić B, Maksimović M, Nedeljković M, 1996, Trimedoxime and HI-6: Kinetic Comparison after Intravenous Administration to Mice, Pharmacol Toxicol, 78, 269-72.

30. Musilek K, Kuca K, Jun D, Dolezal M, 2007, Progress in synthesis of new acetylcholinesterase reactivators in period 1990-2004, Curr Org Chem, 11, 229-38.

31. Patočka J, 1973, Equilibrium kinetics of reactivation of phosphonylated acetylcholinesterase by oximes, Collection Czechoslov Chem Commun, 38, 1996-3003.

32. Pope C, Karanth S, Liu J, 2005, Pharmacology and toxicology of cholinesterase inhibitors: uses and misuses of a common mechanism of action. Environ Toxicol Pharmacol, 19, 433-46.

33. Primožić I, Odžak R, Tomić S, Simeon-Rudolf V, Reiner E, 2004, Pyridinium, imidazolium, and quinucludinium oximes: synthesis, interaction with native and phosphylated cholinesterases, and antidotes against organophosphorus compounds, J Med Chem Def, 2, 1-30.

34. Schoene K, König A, Oldiges H, Krügel M, 1988, Pharmacokinetics and efficacies of obidoxime and atropine in paraoxon poisoning, Arch Toxicol, 61, 387-91.

35. Schoene K, Oldiges $H, 1973$, Efficacy of pyridinium salts in tabun and sarin poisoning in vivo and in vitro, Arch Int Pharmacodyn Ther, 204, 110-23.

36. Schoene K, Strake EM, 1971, Reaktivierung von diethylphosphorylacetylcholinesterase, Biochem Pharmacol, 20, 1041-51. 
Acta Veterinaria (Beograd), Vol. 62, No. 2-3, 123-135, 2012.

Antonijević Biljana et al.: Protective effect of $\mathrm{HI}-6$ and trimedoxime combination

in mice acutely poisoned with tabun, dichlorvos or heptenophos

37. van Helden HP, de Lange J, Busker RW, Melchers BP, 1991, Therapy of organophosphate poisoning in the rat by direct effects of oximes unrelated to ChE reactivation, Arch Toxicol, 65, 586-93.

38. Worek F, Aurbek N, Thiermann H, 2007, Reactivation of organophosphateinhibited human AChE by combinations of obidoxime and HI 6 in vitro, J Appl Toxicol, 27, 582-8

39. Worek F, Kirchner T, Backer M, Szinicz L, 1996, Reactivation by various oximes of human erythrocyte acetylcholinesterase inhibited by different organophosphorus compounds, Arch Toxicol, 70, 497-503.

\title{
ZAŠTITNI EFEKAT KOMBINACIJE HI-6 I TRIMEDOKSIMA U MIŠEVA AKUTNO TROVANIH TABUNOM, DIHLORVOSOM ILI HEPTENOFOSOM
}

\author{
ANTONIJEVIĆ BILJANA, VUČINIĆ SLAVICA i ĆUPIĆ V
}

\begin{abstract}
SADRŽAJ
Cilj ovog rada je bio da se uporedi zaštitni efekat pojedinačnih oksima HI-6 i trimedoksima sa zaštitnim efektom njihove kombinacije u miševa akutno trovanih tabunom, dihlorvosom ili heptenofosom. Oksim HI-6 nije štitio eksperimentalne životinje od trovanja, ali je trimedoksim bio veoma efikasan u antagonitovanju toksičnih efekata sva tri organofosforna jedinjenja. ED-50 0 doze trimedoksima potrebne da zaštite $50 \%$ životinja pri istovremenoj primeni organofosfata i oksima iznosile su 42,18, 14,97 i 32,08 $\mu \mathrm{mol} / \mathrm{kg}$ kod trovanja dihlorvosom, heptenofosom odnosno tabunom. Poluvreme efikasnosti trimedoksima u tretmanu sa tabunom bilo je dva odnosno tri puta duže od poluvremena izračunatih kod trovanja heptenofosom odnosno dihlorvosom. Dodatak trimedoksima doveo je do značajnog poboljšanja zaštitnog efekta HI-6 kod trovanja tabunom. Dodatak trimedoksima takođe je poboljšao zaštitni efekat HI-6 i kod ostala dva otrova, ali je zaštita i dalje bila najbolja kada je primenjen sam trimedoksim. Ispitivanja različitih kombinacija oksima ukazuju da je primena smeše dva oksima opravdani pristup u prevazilaženju problema nejednake efikasnosti oksima.
\end{abstract}

